\title{
FINE STRUCTURE OF THE CENTRAL NERVOUS SYSTEM OF DERMACENTOR VARIABILIS (SAY), AMBLYOMMA AMERICANUM (L.), AND ARGAS ARBOREUS KAISER, HOOGSTRAAL, AND KOHLS (IXODOIDEA)*
}

\begin{abstract}
Lewis B. Coons, $\uparrow$ Mohamed A. Roshdy,
ABstract: The central nervous system of unfed male Dermacentor variabilis (Say) and female Amblyomma americanum (L.) (Ixodidae), and female Argas (Persicargas) arboreus Kaiser, Hoogstraal, and Kohls (Argasidae) was studied by light microscopy using epon sections stained with Azure II and PAS, and by transmission electron microscopy. The fused central nervous system is enclosed within a periganglionic blood sinus and penetrated by the esophagus. This system consists of an outer neural lamella containing layers of homogeneous finely granular material and periodically cross-banded collagenous fibrils, a cortex of perineurium, glial cells, at least 3 neuronal types, and an inner neuropile of nerve fibers (axons and dendrites) partially ensheathed by glial processes. Large intracellular spaces occur in perineural glial cells in A. arboreus, but heavy glycogen deposits are observed in perineurium of $D$. variabilis and A. americanum. The fine structure of the nervous tissue and of a peripheral nerve is compared to that of insects and mites as a basis for investigating structural changes in ticks infected by viruses and rickettsias.
\end{abstract}

The general anatomy and histology of the tick central nervous system have been studied by Robinson and Davidson (1913), Douglas (1943), Sonenshine (1970), and Eichenberger (1970). Ioffe (1963), Tsvilleneva (1965), and Eichenberger (loc. cit.) described the cel-

Received for publication 14 December 1973.

* From Research Projects MR041.09.01-0037A 6HJ and MF51.524.009-3010B F61, Bureau of Medicine and Surgery, Department of Navy, Washington, D. C. The opinions and assertions contained herein are the private ones of the authors and are not to be construed as official or as reflecting the views of the Department of Navy or of the naval service at large. This work was also supported in part by a special grant from the Office of Naval Research and by Agreement 03-005-01 between the NIAID (NIH) and NAMRU-3.

$\dagger$ Electron Microscope Center, Department of Entomology, Mississippi State University, Drawer EM, Mississippi State, Mississippi 39762. Publication No. 2747. Mississippi Agricultural and Forestry Experiment Station.

\$ Department of Zoology, Faculty of Science, Ain Shams University, and Consultant, Medical Zoology Department, U. S. Naval Medical Research Unit Number Three (NAMRU-3), U. S. Interests Section, c/o Spanish Embassy, Cairo, Arab Republic of Egypt.

$\S$ Department of Entomology, North Carolina State University, Raleigh, North Carolina 27607, where this microscopy was conducted with support from the Office of Naval Research, Naval Biology Program Contract N00014-70-A-0120001 (R. C. Axtell, principal investigator). lular organization and fiber tract interconnections in the supraesophageal and subesophageal portions of the nerve mass of several ixodid and argasid ticks. Neurosecretory cells in nervous tissues were demonstrated by Gabe (1955), Ioffe (1964, 1965), Dhanda (1967), and Eichenberger (loc. cit.).

However, the fine structure of the central nervous system is less known in acarines than in insects. Recently, Eichenberger (loc. cit.) and Chow et al. (1972) gave brief electron microscope descriptions of some structures in the nervous tissue of Ornithodoros moubata (Murray) and Rhipicephalus sanguineus Latreille, respectively, and Coons and Axtell (1971) studied the cellular organization in the synganglion of the mite Macrocheles muscaedomesticae (Scopoli).

In studies to increase knowledge of tick internal organs at the electron microscopic level, we described the fine structure of Dermacentor variabilis (Say) salivary glands (Coons and Roshdy, 1973) and of a neurohemal organ in Argas (Persicargas) arboreus Kaiser, Hoogstraal, and Kohls (Roshdy et al., 1973). The present paper describes the fine structure of the central nervous system of $\mathrm{Der}$ macentor variabilis (Say) and Amblyomma americanum L. (Ixodidae) and of A. (P.) arboreus (Argasidae) and provides basis for further investigations of this organ in pathogeninfected ticks. 


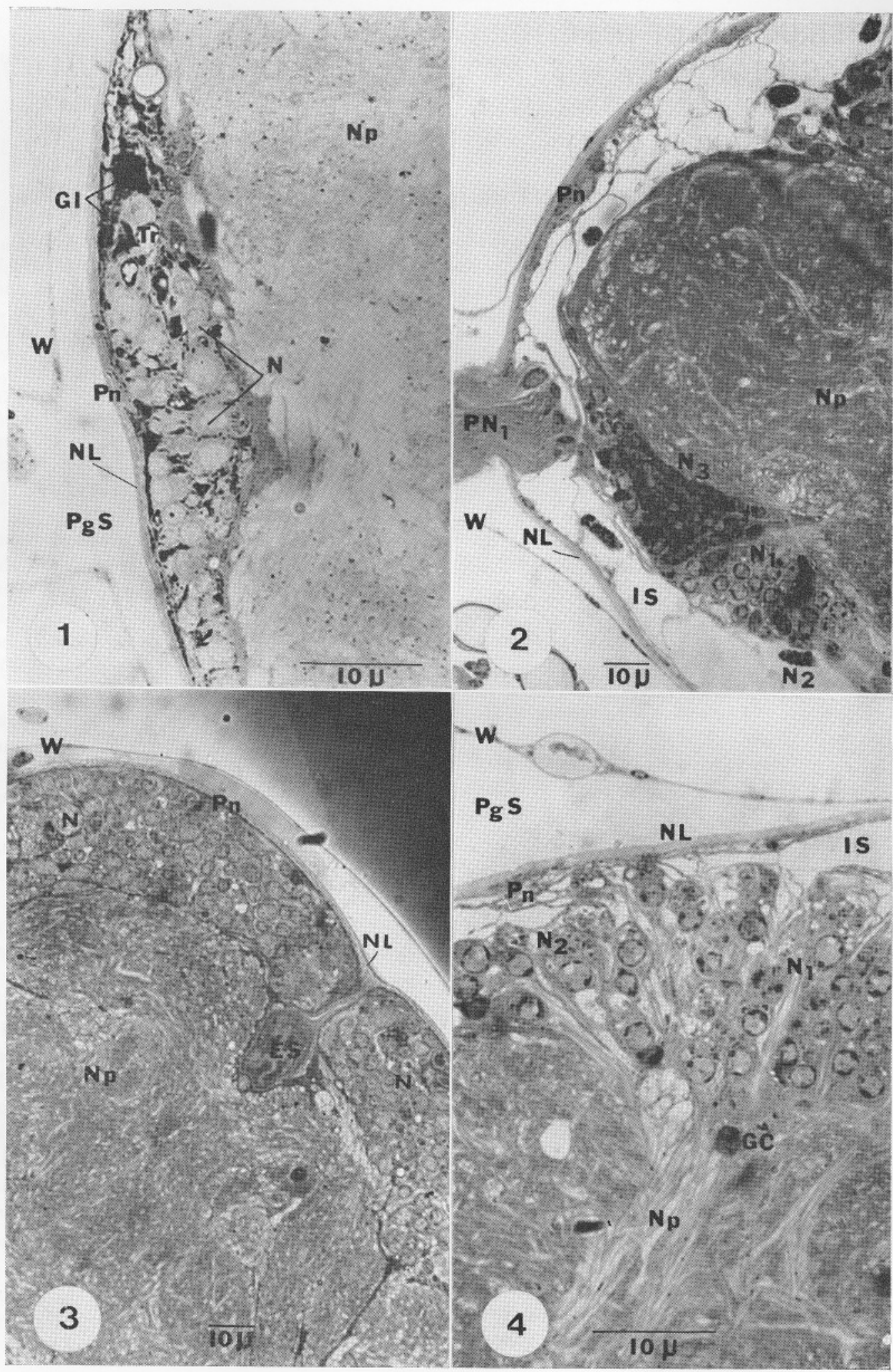




\section{MATERIALS AND METHODS}

Ticks investigated were unfed male $D$. variabilis and virgin female A. americanum collected from nature near Raleigh, North Carolina, and unfed virgin female $A$. (P.) arboreus from a laboratory colony originating from the type locality of this species near Cairo and maintained in the NAMRU-3 Zoology Laboratories.

For electron microscopy, materials were fixed, dehydrated, embedded, and sectioned as previously described (Coons and Roshdy, 1973). Epon-embedded sections, $0.5 \mu$ thick, were stained with Azure II as a general survey stain and with periodic acid-Schiff (PAS) reagent to demonstrate carbohydrates.

\section{RESULTS}

\section{Light microscopy (Figs. 1-4)}

The central nervous system of each species consists of a fused ganglionic mass with peripheral nerves extending to various body organs. This mass is traversed by the esophagus and thus divided into supraesophageal and subesophageal portions which fuse laterally.

As seen in Azure II-stained epon sections (Figs. 2-4), the nervous tissue is surrounded by an extracellular neural lamella and consists of two zones. The outer zone, or cortex, is comprised of perineurium, glial cells, and neuronal cell bodies. The inner zone, or neuropile, consists of nerve fibers (axons and dendrites) and glial cells and contains the esophageal canal. The nervous mass is located in a thinwalled periganglionic blood sinus connected to the heart by the aorta (Roshdy et al., 1973).

In D. variabilis and A. americanum, the perineurium is adjacent to the neural lamella and some cells contain heavy deposits of PASpositive material, possibly glycogen (Fig. 1). However, in A. (P.) arboreus, the perineural cells form large intracellular spaces or "vacuoles" demarcated by a network of cell membranes (Fig. 2). Few glycogen deposits were observed in the cell cytoplasm.

Three major types of neurons (N 1-3) in the cortical region of each tick species correspond to the motor or association-motor neurons, neurosecretory neurons, and globuli cells, respectively, described by previous authors. The globuli cells with characteristic, intensely staining nuclei, are packed in a paired mass lying in the first pedal ganglia (Fig. 2). Glial cell bodies and processes are often observed between the neurons and in the neuropile.

\section{Transmission electron microscopy (Figs. 5-22)}

Neural lamella: The ultrastructure of the neural lamella is the same in each species examined (Figs. 5-8). This external connective tissue sheath ( 2 to $5 \mu$ thick) consists of repeated layers of homogeneous, finely granular, disorganized material. The outermost layer is thicker in the two ixodid than in the argasid species. The areas between these layers are occupied by a feltwork of collagenous fibrils showing periodic cross-banding (Fig. 6) and embedded in an amorphous matrix. No organelles were observed in the neural lamella.

Axons containing neurosecretory vesicles were frequently observed in the neural lamella (Figs. 5, 7, 8). Examination of serial sections showed these axons ending near the neural lamella surface with no evidence of axonal extensions into the periganglionic sinus.

Perineurium: Beneath the neural lamella lies a complex series of glial cell layers forming the perineurium (Figs. 8-10). Cells bordering the neural lamella have more irregular membranes enclosing narrow intercellular (or extracellular) spaces, axons containing neurosecretory vesicles, and tracheal elements. Junctional specializations were not observed between adjacent cell membranes. In both $D$. variabilis and A. americanum, perineaural cells containing heavy glycogen deposits (identified by characteristic rosette appearance) form an ap-

$\leftarrow$

Figures 1-4. Photomicrographs of cross sections of the tick central nervous system. 1. Dermacentor variabilis showing heavy deposits of glycogen $(\mathrm{Gl})$ in the perineural glial cells (Pn) and processes (PAS reaction). 2. Argas (Persicargas) arboreus at the level of first pedal nerve $\left(\mathrm{PN}_{1}\right)$ showing types 1,2 , and 3 neurons $\left(\mathrm{N}_{1}-\mathrm{N}_{3}\right)$ and intracellular spaces (IS) in the perineurium (Pn) (Azure II stain). 3. Amblyomma americanum showing compact neurons $(\mathrm{N})$ in the cortex and absence of intracellular spaces in the perineurium ( $\mathrm{Pn}$ ) (Azure II stain). 4. Argas (Persicargas) arboreus showing type $1\left(\mathrm{~N}_{1}\right)$ and type $2\left(\mathrm{~N}_{2}\right)$ neurons and glial cell bodies (GC) in a ganglion. Es, esophagus; Np, neuropile; NL, neural lamella; PgS, periganglionic blood sinus; W, wall of blood sinus (Azure II stain). 


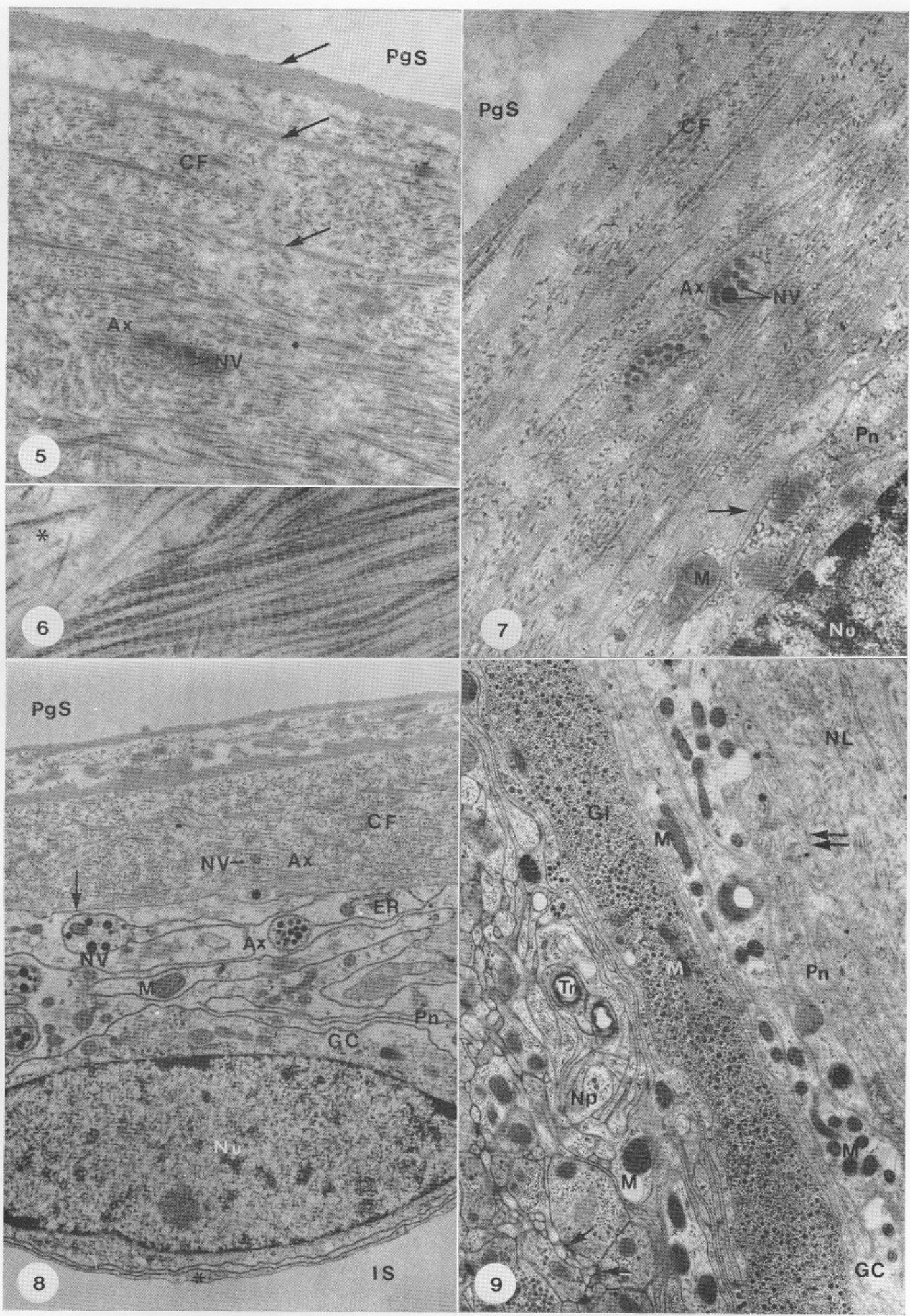


parently continuous layer surrounding neuronal cell bodies in the cortex. However, in A. (P.) arboreus, glial cells in the perineurium form an extensive system of tortuous extensions containing large intracellular spaces, or empty, membrane-bound vacuoles (Figs. 8, 10). The very thin cytoplasm surrounding these spaces contains mitochondria, microtubules, free ribosomes, and small vacuoles (Fig. 10, insert). Contiguous surface membranes of adjacent cells enclose narrow intercellular spaces and lack junctional specializations.

Glial cells: Other glial cells are found between neuronal cell bodies in the cortex and at the neuropile periphery. Glial cells investing neurons (Figs. 11-18) have several glial sheaths which may extend into deep invaginations on the surface membranes of the perikaryia (Fig. 17). Glial cell bodies contain smooth endoplasmic reticulum, mitochondria, microtubules, and glycogen deposits. Extracellular spaces filled with amorphous electron-dense material are frequently observed between glial cells in the cortex of ixodid ticks but not the argasid tick (Fig. 18).

Neurons: This study is not concerned with identifying functional types of neurons, which is better accomplished by the light microscope. At a descriptive level, we attempt to divide neurons in the cortical region into three major types of neuronal cells bodies which are consistently present in the tick species investigated.

Type 1 neurons (6 to $9 \mu$ ), commonly distributed in all ganglionic centers, are characterized by a large nucleus and a relatively small cytoplasmic volume. The perikaryia contain free ribosomes, rough endoplasmic reticulum, mitochondria, a Golgi region, and lysosomelike bodies. Occasional "dark" neurons, similar to those described for the mite Macrocheles muscaedomesticae (Coons and Axtell, 1971), were observed in the nervous tissues of both ixodids and the argasid tick.

Type 2 neurons are neurosecretory cells (Figs. 15-17) distributed among other neurons. These cells, 5 to $15 \mu$ in diameter, differ from type 1 neurons by having a much greater cytoplasmic volume. The cytoplasm contains numerous membrane-bound electron-dense neurosecretory vesicles apparently manufactured in the Golgi region (Fig. 16), mitochondria, rough endoplasmic reticulum, and lysosomelike bodies.

Type 3 neurons, grouped in a paired mass in the first pedal ganglia of both ixodid and argasid ticks (Figs. 2, 13, 14), are uniform in size (ca. $6 \mu$ ) and ultrastructure. Nuclei containing large, electron-dense clumps of chromatin occupy most of the cell body. The cytoplasm contains a few mitochondria, rough endoplasmic reticulum, and free ribosomes. Glial ensheathment of these closely packed neurons is much narrower than that of other neuronal types and sometimes absent between contiguous cell membranes (Fig. 13).

Neuropile. Glial cells: Within the neuropile, glial cells originate from two different sources, from extensions of the cortex glial cell layers (Figs. 11, 19) and from spiderlike glial cells originating in the neuropile (Fig. 20). These latter cells partially ensheath nerve fibers and surround tracheal elements by an extensive system of glial processes several microns in length. The cytoplasm contains numerous mitochondria, microtubules, free ribosomes, a small amount of rough and smooth endoplasmic reticulum and scattered glycogen deposits. In

Figures 5-9. Transmission electron micrographs of neural lamella and perineurium in the tick central nervous system. 5. Neural lamella of Amblyomma americanum showing repeated layers of homogeneous material (arrows) and collagen fibrils (CF) embedded in amorphous matrix. An axon (Ax) containing neurosecretory vesicles (NV) is found within the neural lamella. PgS, periganglionic blood sinus. $\times 15,000$. 6. High magnification view of collagen fibrils in the neural lamella of Amblyomma americanum showing cross-banding periodicity. Asterisk indicates amorphous matrix. $\times 40,000$. 7 . Neural lamella and perineurium ( $\mathrm{Pn}$ ) of Dermacentor variabilis. Arrow indicates perineural cells bordering neural lamella. Nu, nucleus; M, Mitochondrion; rest as in Fig. 5. $\times 15,000.8$. Neural lamella and perineurium ( $\mathrm{Pn}$ ) of Argas (Persicargas) arboreus. A large intracellular space (IS) is shown in a perineural cell whose cytoplasm is indicated by asterisk. GC, glial cell; ER, rough endoplasmic reticulum; rest as in Figs. 5 and $7 . \times 9,700$. 9. Perineurium of Amblyomma americanum showing perineural cell containing large glycogen deposits (Gl). Double arrows indicate border of perineurium and neural lamella. Single arrows indicate synaptic area in neuropile $(\mathrm{Np})$. Tr, trachea; rest as in Figs. 5, 7, 8. $\times 7,500$. 


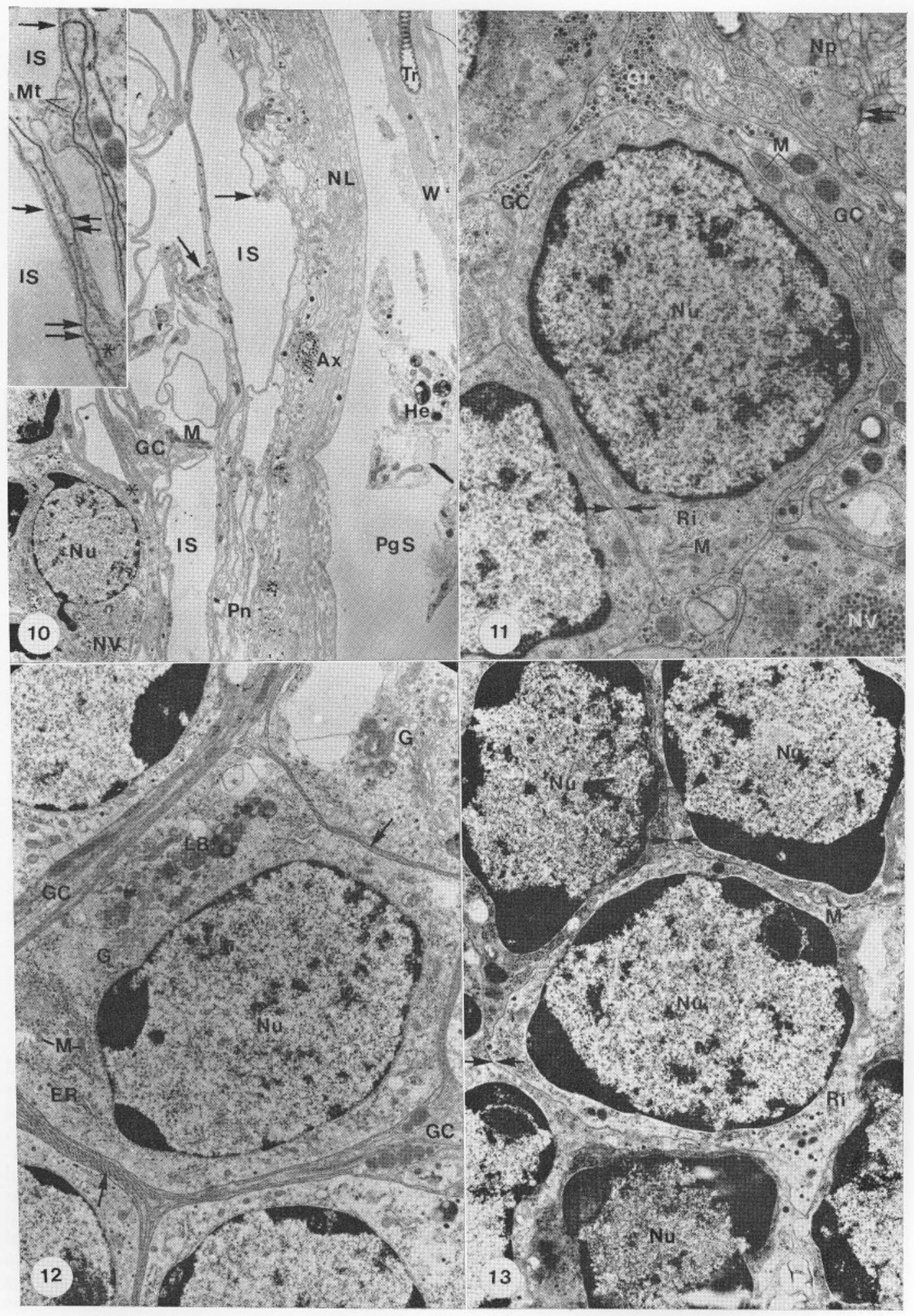


the ixodid ticks, extracellular spaces similar in structure and probably contiguous with those in the cortex are found in the glial cells and their extensions.

Nerve fibers: The neuropile, the most complex region of tick nervous tissue, is almost filled by nerve fibers (axons and dendrites), 0.13 to $5.0 \mu$ in diameter, which are partially ensheathed by thin glial cell processes (Figs. 19-21). Unsheathed nerve fiber (Fig. 20) contacts are of three forms: longitudinal, cross, and end-knob. Synaptic areas appearing as dark, thickened membranes are also found between contiguous unsheathed nerve fibers (Fig. 9).

The nerve fibers contain numerous neurotubules, peripheral mitochondria, free ribosomes, a few scattered rough and smooth endoplasmic reticulum, and random glycogen deposits. Axons containing neurosecretory vesicles identical to those in neurosecretory cell bodies are common in the neuropile.

Esophageal canal: The esphagus, penetrating the neuropile through an esophageal canal (Fig. 21), divides the nervous mass into supraesophageal and subesophageal portions. The esophageal canal is lined by a thin $(0.3$ $\mu$ ) layer of amorphous material containing little fibrillar organization and apparently continuous with the outermost layer of the neural lamella (Fig. 3). This layer is underlined by numerous glial cells similar to those in the perineurium. The general organization of the esophageal canal resembles that of the mite Macrocheles muscaedomesticae (Coons and Axtell, 1971).

Peripheral nerves: Peripheral nerves arising from the various ganglionic centers extend to different organs. Sensory and motor axons are mixed in these nerves (Tsvileneva, 1965).

Enclosed within a limited hemolymph space extending from the periganglionic sinus (Fig. 2 ), each nerve is ensheathed by a thin neural lamellar extension. The neural lamella of the nerve, $0.6 \mu$ thick, shows little organization and contains no demonstrable collagenous fibrils (Fig. 22). Light areas in the lamella appear to contain fine fibrillar structures. Lamellar invaginations extend deeply throughout the nerve and ensheath individual nerve fibers, 0.26 to $6 \mu$ in diameter.

Glial cell bodies below the neural lamella contain sparse mitochondria, membranous cisternae, and numerous microtubules oriented almost parallel to the axons. Thin glial sheets with cytoplasmic traces surround individual axons to form mesaxons. These mesaxons are separated from the axonal surface membranes by thin lamellar involutions originating from the outer neural lamella.

The nerve fiber cytoplasm, or "axoplasm," contains numerous neurotubules, a few mitochondria, and smooth endoplasmic reticulum. Some axons contain neurosecretory vesicles.

Smaller nerve fibers are usually grouped. They have few glial cell extensions and are separated from each other by thin lamellar material.

\section{DISCUSSION AND CONCLUSIONS}

The tick nervous system is an important site for spirochete growth and multiplication (Burgdorfer, 1951) and viruses and rickettsias also develop in this system ( Reháček, 1965). Observations on the nervous system structure in uninfected ticks should be followed by com-

\section{$\leftarrow$}

Figures 10-13. Transmission electron micrographs of cortical region in the tick central nervous system. 10. Low magnification of cortical region of Argas (Persicargas) arboreus showing extensive intracellular space (IS). Single arrows indicate cytoplasm bordering spaces in glial cells (GC). Asterisk indicates glial ensheathment. Ax, axon containing neurosecretory vesicles; $\mathrm{He}$, hemocyte; $\mathrm{M}$, mitochondrion; $\mathrm{Nu}$, nucleus of neurosecretory cell; NL, neural lamella; NV, neurosecretory vesicles; PgS, periganglionic blood sinus; $\mathrm{Pn}$, perineurium; W, wall of blood sinus. $\times 3,000$. Insert: Higher magnification of intracellular spaces (IS) showing membrane-bound spaces (single arrow), glial cell cytoplasm (asterisk), and adjacent cell membranes (double arrows). Mt, microtubules. $\times 15,000$. 11. Type 1 neurons of A. americanum. Single arrows indicate narrow glial extensions between two neurons. Double arrows indicate synaptic area in neuropile ( $\mathrm{Np}$ ). GC, glial cell body; Gl, glycogen; M, mitochondrion; Nu, nucleus of type 1 neuron; NV, neurosecretory vesicles; Ri, free ribosomes. $\times 7,500$. 12. Type 1 neuron of Argas (Persicargas) arboreus. ER, rough endoplasmic reticulum; G, Golgi region; LB, lysosomelike bodies; rest as in Fig. $11 . \times 5,000$. 13. Type 3 neurons of Argas (Persicargas) arboreus. Arrows indicate direct contact between cell membranes of adjacent neurons; rest as in Figs. 11, 12. $\times 4,700$. 


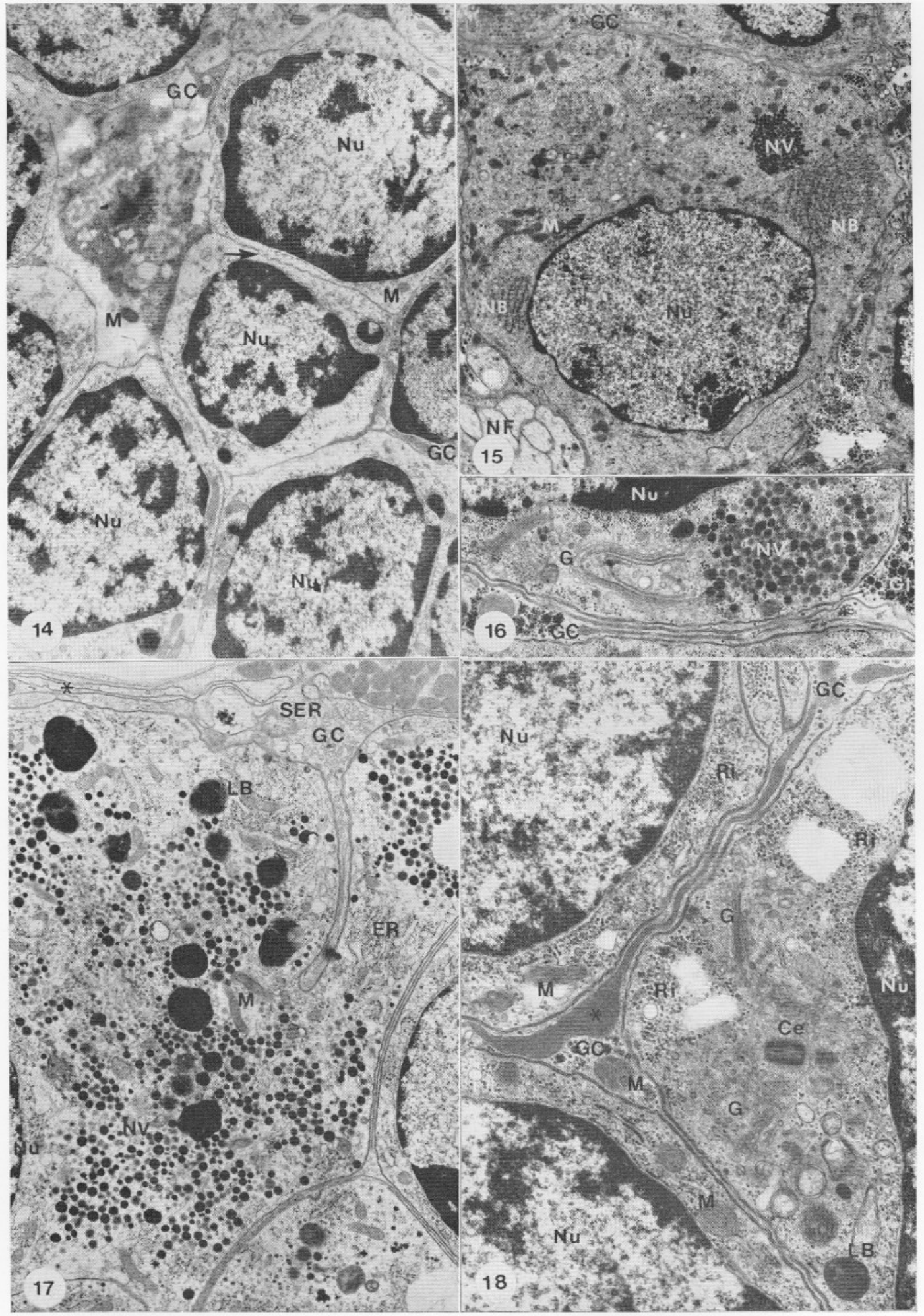


parative studies of infected ticks in the hope of discovering weak lines in the pathogen-tick association that may be utilized for biological control.

The general organization of the central nervous system in the unfed adult $D$. variabilis and A. americanum (Ixodidae) and A. (P.) arboreus (Argasidae) conforms to that described for other tick species by using the light microscope (Ioffe, 1963; Tsvileneva, 1965; Eichenberger, 1970), and to that of insects by using the electron microscope (Hess, 1958; Wigglesworth, 1960; Smith and Treherne, 1963; Smith, 1968) and to the mite Macrocheles (Coons and Axtell, 1971).

The composite fine structure of the neural lamella in the three tick species suggests a closer structural similarity to insects than mites. Histochemical and electron microscopic investigations of the insect neural lamella have demonstrated the collagenous nature of the periodically cross-banded fibrils which are embedded in a mucopolysaccharide matrix (Ashhurst, 1968; Treherne and Pichon, 1972). Like insects the outer, homogeneous, finely granular layer in the neural lamella appears to be repeatedly deposited between the fibrillar layers. In the mite Macrocheles, the neural lamella is a single homogeneous layer lacking fibrillar structures (Coons and Axtell, 1971).

Tick and insect neural lamella possibly function similarly. In insects, they are assumed to provide support to underlying tissues, resist positive hydrostatic pressure, and allow relative permeability to nutrients and ionic exchange (Smith and Treherne, 1963; Ashhurst, 1968; Ashhurst and Costin, 1971; Treherne and Pichon, 1972).

We find a notable difference between the ixodid and argasid ticks in the structural organization of the perineural glial cells. The large intracellular spaces or "vacuoles" observed in the perineural cells are characteristic of $A$. $(P$.$) arboreus. These spaces may be a common$ feature of argasids, as they were also observed in A. (P.) persicus (our unpublished observations) and O. moubata (Eichenberger, 1970, fig. 7). Similar but mainly extracellular spaces forming a "glial lacunar system" in the perineurium of several insects were described by Wigglesworth (1960), Smith and Treherne (1963), Smith (1968), and others. These spaces are known to play an important trophic role in nervous tissues. Therefore, it is reasonable to assume that the intracellular spaces in the argasid nervous system are analogous to the insect glial lacunar system, and that soluble nutrients may be stored or passed through these vacuolar spaces to underlying neurons. However, the ixodid ticks possess no such intracellular spaces but instead have large glycogen deposits in the perineural glial cells. It is uncertain whether this difference in perineurium structure in argasid and ixodid ticks is related to the remarkable difference in feeding habits of both families, a factor possibly influencing nutritional requirements and reserves in the nervous tissues.

The presence of three types of neurons in the nervous tissues of $D$. variabilis, A. americanum, and A. arboreus conforms with light microscopic observations in other tick species (Ioffe, 1963; Tsvileneva, 1965; Eichenberger, 1970). Type 1 neurons correspond to motor or association-motor neurons, type 2 to neurosecretory cells, and type 3 to "olfactory" globuli cells in the first pedal ganglia, as described by these authors. Chow et al. (1972), working on the Rhipicephalus sanguineus brain, classified neurons into motor and ganglionic cells, the latter including neurosecretory, spherical nucleus, and irregular nucleus neurons. The

Figures 14-18. Transmission electron micrographs of neurons in the tick central nervous system. 14. Type 3 neurons in Dermacentor variabilis; lettering as in Fig. 13. $\times 11,600$. 15. Type 2 neurons in Amblyomma americanum. GC, glial cell; M, mitochondrion; Nu, nucleus; NB, Nissl bodies; NF, nerve fibers; $\mathrm{NV}$, neurosecretory vesicles. $\times 4,500$. 16. Golgi region (G) in type 2 neurons of Amblyomma americanum showing electron lucent and dense neurosecretory vesicles (NV). Gl, glycogen; GC, glial cell. $\times 15,000$. 17. Type 2 neurons in Argas (Persicargas) arboreus. A glial cell (GC) process containing smooth endoplasmic reticulum (SER) invaginates into the perikaryion of type 2 neuron. Asterisk indicates glial sheets. ER, rough endoplasmic reticulum; LB, lysosomelike bodies; rest as in Fig. 15. $\times 8,700$. 18. Extracellular material (asterisk) between glial cells (GC) ensheathing type 1 neurons in Amblyomma americanum. Ce, centriole; Ri, free ribosomes; rest as in Figs. 16, 17 . $\times 15,400$. 


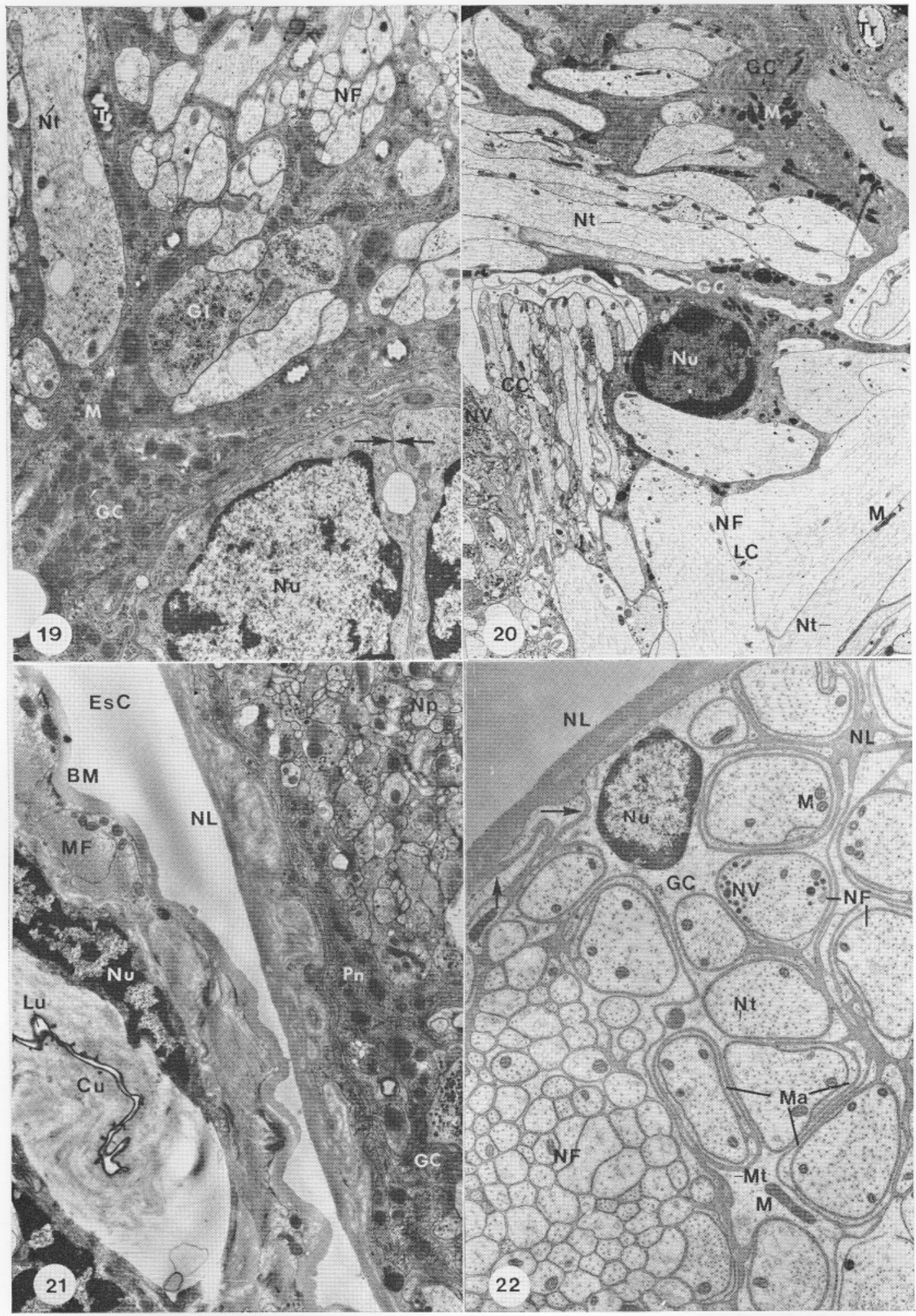


so-called irregular nucleus neurons illustrated by these authors apparently represent a glial cell adjacent to a neurosecretory cell body.

The fine structure of the tick neurons agrees with that described for several insects and a mite. Unlike mites (Coons and Axtell, 1971), glial ensheathment of types 1 and 2 neurons is complete, and direct contact between adjacent cell membranes was observed only in type 3 neurons. Furthermore, glial extensions invaginate into the neuronal cell bodies, a feature probably related to the transfer of trophic material (Smith, 1968).

Neurosecretory cells commonly distributed in the tick nerve ganglia (Ioffe, 1964; Dhanda, 1967; Eichenberger, 1970) contain electrondense vesicles manufactured in the Golgi region and distributed in the cell bodies and axons. It is interesting to mention that fine axons containing neurosecretory vesicles were observed in the neural lamella. These axons may release neurosecretory contents directly into the hemolymph in the periganglionic sinus. Other axons containing neurosecretory material are also found in the neuropile and peripheral nerves.

The overall morphology of the nerve fibers and glial cells, as well as the contacts between individual axons and dendrites, in the neuropile region is identical in all three tick species and conforms to the neuropile arrangement in insects and in Macrocheles (Coons and Axtell, 1971). The fine structure of the tick esophageal canal is essentially similar to that of the mite.

As in insects (Smith, 1968), tick peripheral nerve fibers are neither myelinated or unmyelinated, but rather fall into a third morphological category termed "tunicated." In this category, nerve fibers are ensheathed by mesaxons from glial extensions. A remarkable difference between insect and tick nerves is the presence of extensive invaginations of the tick neural lamella surrounding individual fibers before mesaxon ensheathment. This feature is not found in insects. The smaller, usually grouped nerve fibers of ticks lack individual mesaxon ensheathment. The functional significance of this orientation in tick peripheral nerves is unknown.

\section{ACKNOWLEDGMENT}

We are greatly indebted to Dr. Harry Hoogstraal for continuous encouragement and interest in this work and for critically reading the manuscript.

\section{LITERATURE CITED}

Ashrurst, D. E. 1968. The connective tissues of insects. Ann. Rev. Ent. 13: 45-74.

—, AND N. M. Costin. 1971. Insect mucosubstances. II. The mucosubstance of the central nervous system. Histochem. J. 3: 297-310.

Burgdorfer, W. 1951. Analyses des Infectionsverlaufes bei Ornithodorus moubata (Murray) und der natürlichen Uebertragung von spirochaeta duttoni. Acta Trop. 8: 193-262.

Chow, Y. S., S. H. Lin, And C. H. WANG. 1972. An ultrastructural and electrophysiological study of the brain of the brown dog-tick, Rhipicephalus sanguineus (Latreille). Chinese Bioscience 1: 83-92.

Coons, L. B., And R. C. Axtell. 1971. Cellular organization in the synganglion of the mite Macrocheles muscaedomesticae (Acarina: Macrochelidae). An electron microscopic study. Z. Zellforsch. 119: 309-320.

$\longrightarrow$, AND M. A. Roshdy. 1973. Fine structure of the salivary glands of unfed male Derma-

$\leftarrow$

Figures 19-22. Transmission electron micrographs of neuropile and peripheral nerve in the tick nervous system. 19. Neuropile of Amblyomma americanum. A complex series of glial cell (GC) extensions partially ensheath nerve fibers (NF), and surround neurons (arrows) in the cortex. Gl, glycogen; M, mitochondrion; $\mathrm{Nu}$, nucleus; $\mathrm{Nt}$, neurotubules in nerve fibers; $\mathrm{Tr}$, tracheal elements surrounded by glial cell extensions. $\times 6,200$. 20. Neuropile of Argas (Persicargas) arboreus showing a glial cell (GC) extension between nerve fibers (NF). Nerve fibers are partially ensheathed and show direct longitudinal (LC) and cross $(\mathrm{CC})$ contacts. NV, neurosecretory vesicles; rest as in Fig. 19. $\times 4,000.21$. Esophageal canal (EsC), containing esophagus, in the neuropile ( $\mathrm{Np}$ ) of Amblyomma americanum. BM, basement membrane of esophagus; $\mathrm{Cu}$, cuticle; $\mathrm{Gl}$, glial cell; $\mathrm{Lu}$, lumen of esophagus; $\mathrm{MF}$, muscle fiber; $\mathrm{Nu}$, nucleus of epithelial cell in esophagus; NL, neural lamella lining esophageal canal; Pn, perineurium. $\times 5,000.22$. Peripheral nerve of Dermacentor variabilis. Arrows indicate invaginations of neural lamella (NL) to surround individual nerve fibers (NF). Glial cell (GC), also surrounded by neural lamellar material, forms mesaxons (Ma) around nerve fibers. $\mathrm{M}$, mitochondrion; Mt, microtubules; $\mathrm{Nt}$, neurotubules; $\mathrm{Nu}$, nucleus of glial cell; Nv, neurosecretory vesicles. $\times 7,500$. 
centor variabilis (Say) (Ixodoidea: Ixodidae). J. Parasitol. 59: 900-912.

DHANDA, V. 1967. Changes in neurosecretory activity at different stages in the adult Hyalomma dromedarii Koch, 1844. Nature 214: 508-509.

Douglas, J. R. 1943. The internal anatomy of Dermacentor andersoni (Stiles). Univ. Calif. Publ. Entomol. 7: 207-272.

Eichenberger, G. 1970. Das Zentral-nervensystem von Ornithodorus moubata (Murray), Ixodoidea: Argasidae, und seine postembryonale Entwicklung. Acta Trop. 27: 15-53. (In English: NAMRU3-T419.)

GABE, M. 1955. Données histologiques sur la neurosecretion chez les Arachnides. Arch. Anat. Microsc. Morphol. Exp. 44: 351-383.

Hess, A. 1958. The fine structure of nerve cells and fibers, neuroglia and sheaths of the ganglion chain in the cockroach (Periplaneta americana). J. Biophys. Biochem. Cytol. 4: 731-742.

IofFE, I. D. 1963. Der bau des Nervenapparats von Dermacentor pictus Herm. (Chelicerata, Acarina). (In Russian: German summary.) Zool. Zh. 42: 1472-1484. (English translation: TT64-19707.)

- 1964. Distribution of neurosecretory cells in the central nervous system of Dermacentor pictus Herm. (Acarina, Chelicerata). (In Russian.) Dokl. Akad. Nauk SSR 154: 229232. (In English: NAMRU3-T326.)

- 1965. Seasonal changes of neurosecretion contents in the neurosecretory cells of Dermacentor pictus Herm. (Ixodoidea, Acarina).
(In Russian; English summary.) Med. Parazit., Moskva 34: 57-68.

ŘEHÁČEK, J. 1965. Development of animal viruses and rickettsiae in ticks and mites. Ann. Rev, Ent. 10: 1-24.

Robinson, L. E., and J. Davidson. 1913. The anatomy of Argas persicus (Oken). Parasitology 6: 382-430.

Roshity, M. A., N. M. Shoukrey, and L. B. Coons. 1973. The subgenus Persicargas (Ixodoidea, Argasidae: Argas). 17. A neurohemal organ in A. (P.) arboreus Kaiser, Hoogstraal, and Kohls. J. Parasitol. 59: 540-544.

Sмгтн, D. S. 1968. Insect Cells: Their Structure and Function. Oliver and Boyd, Edinburgh, $372 \mathrm{p}$.

-, And J. E. Treherne. 1963. Functional aspects of the organization of the insect nervous system. Adv. Insect Physiol. 1: 401-484.

Sonenshine, D. E. 1970. A contribution to the internal anatomy and histology of the bat tick Ornithodoros kelleyi Cooley and Kohls, 1941. II. The reproductive, muscular, respiratory, excretory, and nervous system. J. Med. Entomol. 7: 289-312.

Treherne, J. E., And Y. Pichon. 1972. Insect blood barrier. Adv. Insect Physiol. 9: $257-$ 313.

Tsvileneva, V. A. 1965. The nervous structure of the ixodid synganglion (Acarina, Ixodoidea). Entomol. Rev. 44: 135-142.

Wigglesworth, V. B. 1960. The nutrition of the central nervous system of the cockroach, Periplaneta americana. The mobilization of reserves. J. Exp. Biol. 37: 500-512. 